\title{
Model Jaringan Transportasi Laut Angkutan Gas Alam Cair untuk Pembangkit Listik di Indonesia Bagian Timur
}

\author{
Irwan Tri Yunianto ${ }^{1}$, Eka Wahyu Ardhi ${ }^{2}$, Desy Anggraini ${ }^{3}$ \\ 1,2,3 Departemen Teknik Transportasi Laut, Institut Teknologi Sepuluh Nopember \\ 1 irwan@seatrans.its.ac.id, ${ }^{2}$ ekawahyu@seatrans.its.ac.id, ${ }^{3}$ deesyanggraini@gmail.com
}

DOI: https://doi.org/10.21107/rekayasa.v13i1.5930

\begin{abstract}
ABSTRAK
Pertumbuhan ekonomi Indonesia yang berada pada rata rata 5,8\% per tahun tidak hanya berdampak pada peningkatan kesejahteraan masyarakat secara umum tetapi juga peningkatan kebutuhan tenaga listrik. PT PLN (Persero) telah mengantisipasi peningkatan permintaan tenaga listrik dengan membuat rencana pengembangan pembangkit listrik. Studi ini bertujuan untuk menentukan model transportasi terpadu angkutan gas alam cair (Liquid Natural Gas (LNG)) untuk pembangkit di Kawasan Timur Indonesia. Metode yang digunakan dalam penelitian ini adalah metode optimasi untuk mendapatkan tipe kapal yang sesuai pada rute terpilih yang memberikan biaya satuan minimum. Hasil optimasi menunjukkan bahwa distribusi gas alam cair ke pembangkit listrik di Indonesia bagian timur adalah dengan suplai langsung dari Kilang Tangguh ke pembangkit listrik di Sorong dengan unit biaya sebesar Rp230.000/ $\mathrm{m}^{3}$, 6 pembangkit listrik disuplai melalui Hub Ambon dengan biaya satuan sebesar Rp280.000/ $\mathrm{m}^{3}, 7$ pembangkit listrik disuplai melalui Hub Ternate dengan unit biaya satuan terendah adalah tujuan Tidore sebesar Rp230.000/ $\mathrm{m}^{3}$ dan 5 sisanya akan disuplai melalui Hub Manokwari dengan biaya satuan terendah adalah tujuan Biak sebesar Rp340.000/ $\mathrm{m}^{3}$.
\end{abstract}

Kata Kunci: biaya satuan, LNG, optimasi, transportasi terpadu

\section{PENDAHULUAN}

Program 35.000 MW (Mega Watt) adalah proyek pemerintah untuk membangun pembangkit listrik mencapai $35.000 \mathrm{MW}$ hingga 2019. Program $35.000 \mathrm{MW}$ ini bertujuan untuk memenuhi kebutuhan listrik masyarakat Indonesia dari Sabang sampai Merauke. Hal ini tentu akan berdampak signifikan bagi pertumbuhan ekonomi di luar Jawa, yang sebelumnya kekurangan suplai listrik. Sebagai bagian dari realisasi program tersebut, PLN akan membangun kurang lebih 54 Pembangkit Listrik Tenaga Gas (PLTG) di Regional Maluku dan Papua untuk pemenuhan jatah pembangunan $1000 \mathrm{MW}$ dari total keseluruhan $35.000 \mathrm{MW}$.

Prioritas pembangunan PLTG di wilayah Indonesia Timur khususnya regional Maluku dan Papua lantaran banyaknya sumber energi gas di wilayah tersebut. Papua dengan mega proyek LNG Tangguh di Teluk Bintuni, Papua Barat, menampung gas alam yang berasal dari beberapa Blok di sekitar Teluk Bintuni, seperti Blok Berau, Blok Wiriagar dan Blok Muturi menempati urutan kedua terbesar penyumbang gas alam setelah Blok Mahakam di Kalimantan Timur. Dengan kapasitas produksi LNG Tangguh saat ini sebesar 7.6 juta ton per tahun (MTPA) dan akan bertambah menjadi 11.4 MTPA saat Train 3 mulai beroperasi tahun 2020 nanti.

\section{Article History:}

Received: September, $4^{\text {th }} 2019$; Accepted: January, $14^{\text {th }} 2020$ ISSN: 2502-5325 (Online) Terakreditasi Peringkat 3 oleh Kementerian Riset, Teknologi dan Pendidikan Tinggi (ARJUNA), berdasarkan Keputusan Direktur Jenderal Penguatan Riset dan Pengembangan No: 23/E/KPT/2019 tanggal 8 Agustus 2019
Hal ini terkait dengan pemanfaatan potensi energi primer per daerah yang tercantum dalam Rencana Usaha Penyediaan Tenaga Listrik (RUPTL) PLN 2017 hingga 2026. Penggunaan jenis pembangkit di tiap wilayah disesuaikan dengan ketersediaan sumber energi setempat atau yang terdekat. Pemerintah fokus pada 'least cost basic energy', mendorong semua daerah memakai energi dasar yang paling kompetitif. Selain itu bauran energi dari gas akan meningkat dari posisi saat ini $25,8 \%$ ke angka $26,7 \%$ dengan tambahan pembangkit 24,4 Gigawatt (GW) dalam 10 tahun mendatang dan sejalan dengan target di Rencana Umum Energi Nasional (RUEN), pembangkit Batubara di 2025 ditargetkan $50 \%$ dari total energi primer, Gas 26\% dan BBM diharapkan hanya kurang dari 0,5\%.

Jika dilihat dari segi penggunaannya, gas alam memiliki keunggulan dibandingkan pemanfaatan sumber bahan bakar jenis HSD dan batubara yaitu sifatnya yang rendah polusi atau dengan kata lain lebih bersih, ramah lingkungan, serta keunggulan dalam hal transportasinya. Dalam LNG supply chain atau rantai pasok LNG terdapat 4 aspek yang saling terkait satu sama lain, yaitu produksi, LNG Plant (liquefaction/pencairan), transportasi (pipa atau LNG Tanker), penyimpanan serta regasifikasi. Wilayah Maluku dan Papua adalah daerah yang umumnya tidak dilalui jaringan pipa gas karena merupakan wilayah kepulauan dengan banyak

\section{Cite this as:}

Yunianto, I.T., Ardhi, E.W., Anggraini, D (2020). Model Jaringan Transportasi Laut Angkutan Gas Alam Cair untuk Pembangkit Listik di Indonesia Bagian Timur, Rekayasa, 13(1), 22-30. doi: https://doi.org/10.21107/rekayasa.v13i1.5930 
pulau-pulau kecil yang tersebar sehingga tidak mungkin seluruh wilayah akan disambung dengan jaringan pipa melintasi lautan, karena dipastikan akan membutuhkan dana yang sangat besar. Selain itu pembangkit yang akan dibangun PLN di kedua wilayah tersebut merupakan pembangkit dengan kapasitas kecil berkisar antara 15 sampai $60 \mathrm{MW}$ karena kebutuhannya tidak sebesar di wilayah Sumatera dan Jawa sehingga membutuhkan pasokan gas yang tidak banyak pula. Untuk daerah seperti ini, distribusi gas lebih efisien menggunakan konsep Small Scale LNG Supply Chain.

Distribusi melalui pipa memang merupakan distribusi yang paling murah, namun untuk Wilayah Maluku dan Papua yang merupakan wilayah dengan banyak pulau serta kebutuhan tiap pembangkit yang tersebar sangat kecil, maka distribusi LNG akan lebih efisien dengan menggunakan kapal LNG mini (Small LNG Tanker). Istilah 'small' merujuk pada volume angkut LNG yang hanya sampai $40.000 \mathrm{~m}^{3}$. Kapal LNG normal umumnya berkapasitas angkut $120.000-270.000 \mathrm{~m}^{3}$ dan berlayar antar benua dengan jarak puluhan ribu mil laut dan waktu layar lebih dari 1 minggu. Sementara Small LNG Tanker digunakan untuk jarak sekitar 1.000 mil laut, dengan waktu layar 3-4 hari. Maka akan cocok jika konsep tersebut di terapkan untuk distribusi LNG di wilayah kepulauan Maluku dan Papua.

Guna mendukung potensi tersebut, tugas akhir ini bertujuan untuk mendesain bagaimana rancangan pola distribusi angkutan LNG yang optimal dan terintegrasi dalam pemanfaatan penggunaan gas di Wilayah Maluku dan Papua sebagai energi alternatif pengganti BBM untuk pembangkit listrik disana dengan menetapkan LNG Tangguh di Papua Barat sebagai kilang pemasok dan menggunakan kapal Small LNG dalam pendistribusiannya.

\section{METODE PENELITIAN}

\section{Tahap Perhitungan Biaya}

Pada tahap ini biaya akan dihitung dengan dua komponen utama yaitu biaya tetap dan biaya variabel. Dimana biaya tetap adalah menggunakan Time Charter Hire karena kapal yang akan digunakan adalah kapal sewa dengan sistem time charter. Sedangkan biaya variabel meliputi biaya bahan bakar, biaya jasa kepelabuhanan, biaya penanganan muatan, biaya penyimpanan, biaya regasifikasi, dan investasi terminal penerima.

\section{Tahap Penentuan Kriteria}

Pada tahap ini sarat kapal dengan kedalaman terminal dilakukan analisis kompatibilitas untuk memastikan alternatif kapal mana saja yang nantinya bisa atau tidak bisa sandar di terminal bongkarnya. Analisis dilakukan dengan membandingkan sarat dari semua opsi kapal dengan kedalaman terminal bongkar di semua rute. Selanjutnya kriteria hari kerja kapal diasumsikan berdasarkan karakteristik ombak dan perairan di wilayah yang dilewati oleh kapal dari titik pelabuhan muat ke titik pelabuhan bongkar. Analisis dilakukan dengan melihat kondisi wilayah perairan yang dilewati kapal setiap bulan dalan satu tahun.

\section{Tahap Optimasi}

Pada tahap ini dilakukan optimasi untuk menentukan pola operasi pengiriman LNG dengan menggunakan Open Solver dari Microsoft Excel. Dengan meminimalkan biaya satuan pengiriman LNG dan variabel keputusan adalah frekuensi dibutuhkan dengan batasan kargo terangkut harus lebih besar sama dengan jumlah demand per tahun untuk masing-masing tujuan.

\section{Tahap Optimalisasi Utilitas Kapal}

Pada tahap ini dilakukan analisis bahwa penggunaan 1 (satu) unit kapal untuk melayani 1 (rute) tidaklah optimum dikarenakan total hari kerja kapal dalam setahun masih jauh dari total maksimumnya untuk beberapa rute tertentu. Oleh sebab itu akan dilakukan optimalisasi jumlah penggunaan kapal dari 1 (satu) unit per rute menjadi 1 (unit) untuk melayani semua rute dengan tujuan untuk menghemat biaya sewa kapal yang ditimbulkan dan memaksimalkan utilitas kapal dalam 1 tahun masa sewanya.

\section{HASIL DAN PEMBAHASAN}

\section{Model Matematis}

\section{Objective Function}

Objective Function dalam model ini adalah mencari minimum biaya satuan. Perumusan biaya satuan didapatkan dari pembagian total kargo terkirim dengan total biaya. Berikut adalah model matematis dari objective function:

Minimum $\mathrm{Z}=\frac{T C_{X}}{\left(D_{L N G}\right)}$

Keterangan:

$$
\begin{array}{ll}
\mathrm{Z} & =\text { Biaya Satuan }\left(\mathrm{Rp} / \mathrm{m}^{3}\right) \\
\mathrm{TC} & =\text { Total Cost }(\mathrm{Rp}) \\
\mathrm{D} & =\text { Permintaan }\left(\mathrm{m}^{3} / \text { tahun }\right) \\
\mathrm{X} & =\text { Kapal LNG }
\end{array}
$$

\section{Decision Variable}

Yang menjadi Decision Variable dalam model ini adalah frekuensi pengiriman dibutuhkan (kali/tahun). Pada model ini frekuensi pengiriman akan menentukan rute mana yang terpilih, dan alat angkut ukuran berapa yang akan melayani rute tersebut.

\section{Constraint}

Dalam merumuskan sebuah model, diperlukan batasan untuk mempersempit kemungkinankemungkinan solusi yang dapat terpilih. Berikut adalah batasan yang digunakan dalam model ini:

1. Supply di masing-masing pelabuhan muat $\geq$ kargo terkirim dari masing-masing pelabuhan.

2. Demand di masing-masing di pelabuhan bongkar $\leq$ kargo terkirim untuk masing-masing pelabuhan bongkar. 
24 | Yunianto, I.T. dkk. Model Jaringan Transportasi Laut Angkutan Gas Alam Cair..

3. Minimum sarat pelabuhan untuk masing-masing rute $>$ sarat kapal

4. Frekuensi dibutuhkan $=$ integer

\section{Penyusunan Model}

Langkah awal yang dilakukan dalam merencanakan rute pengiriman ini adalah mengindentifikasi titik demand dan jumlah muatan ( $\mathrm{m}^{3} \mathrm{LNG}$ ). Setelah mengidentifikasi titik demand, dilakukan analisis untuk menentukan lokasi kilang LNG mana yang mampu untuk memasok kebutuhan seluruh pembangkit di wilayah Maluku dan Papua. Setelah semua titik demand dan supply dapat teridentifikasi, langkah selanjutnya adalah menganalisis jenis alternatif alat angkut bagaimana yang sesuai dengan karakteristik muatan yang diminta. Hingga kemudian, dilakukan perencanaan rute pengiriman yang meliputi perhitungan biaya transportasi dan analisis dengan model optimasi untuk mendapatkan rute yang paling optimum dengan biaya yang minimum.

Pada penelitian distribusi LNG ini, yang menjadi tujuan distribusi adalah pembangkit listrik di Kepulauan Maluku dan Papua. Pembangkit yang direncanakan untuk dipasok sesuai RUPTL hingga tahun 2016 terdiri dari 21 pembangkit di Provinsi Maluku, 16 pembangkit di Provinsi Maluku Utara, 23 pembangkit di Provinsi Papua dan 13 pembangkit di Provinsi Papua Barat. Letak dan daya pembangkit tiap provinsi diilustrasikan pada Gambar 1.

Penentuan lokasi dan jumlah terminal penerima berdasarkan lokasi pembangkit. Idealnya, satu pembangkit dilayani oleh satu terminal penerima dan untuk memudahkan unloading LNG dari kapal ke terminal penerima maka terminal penerima harus terletak di dekat laut. Untuk pembangkit yang lokasinya berdekatan diasumsikan terminal penerima digabung menjadi satu. Total keseluruhan titik pembangkit adalah sebanyak 73 pembangkit dengan jumlah terminal penerima yang akan mengcover seluruhnya adalah sebanyak 30 titik lokasi di tiap-tiap pelabuhan yang ada di wilayah kepulauan Maluku dan Papua. 30 titik tersebut terdiri dari 5 terminal HUB dan 25 terminal peneri-

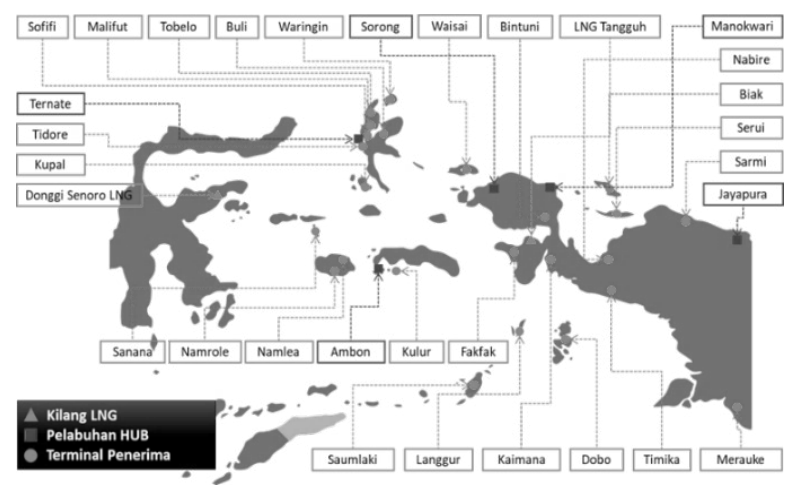

Gambar 1. Persebaran Terminal Penerima di Seluruh Wilayah Maluku dan Papua
Tabel 1. Total Permintaan LNG di Tiap Terminal Penerima

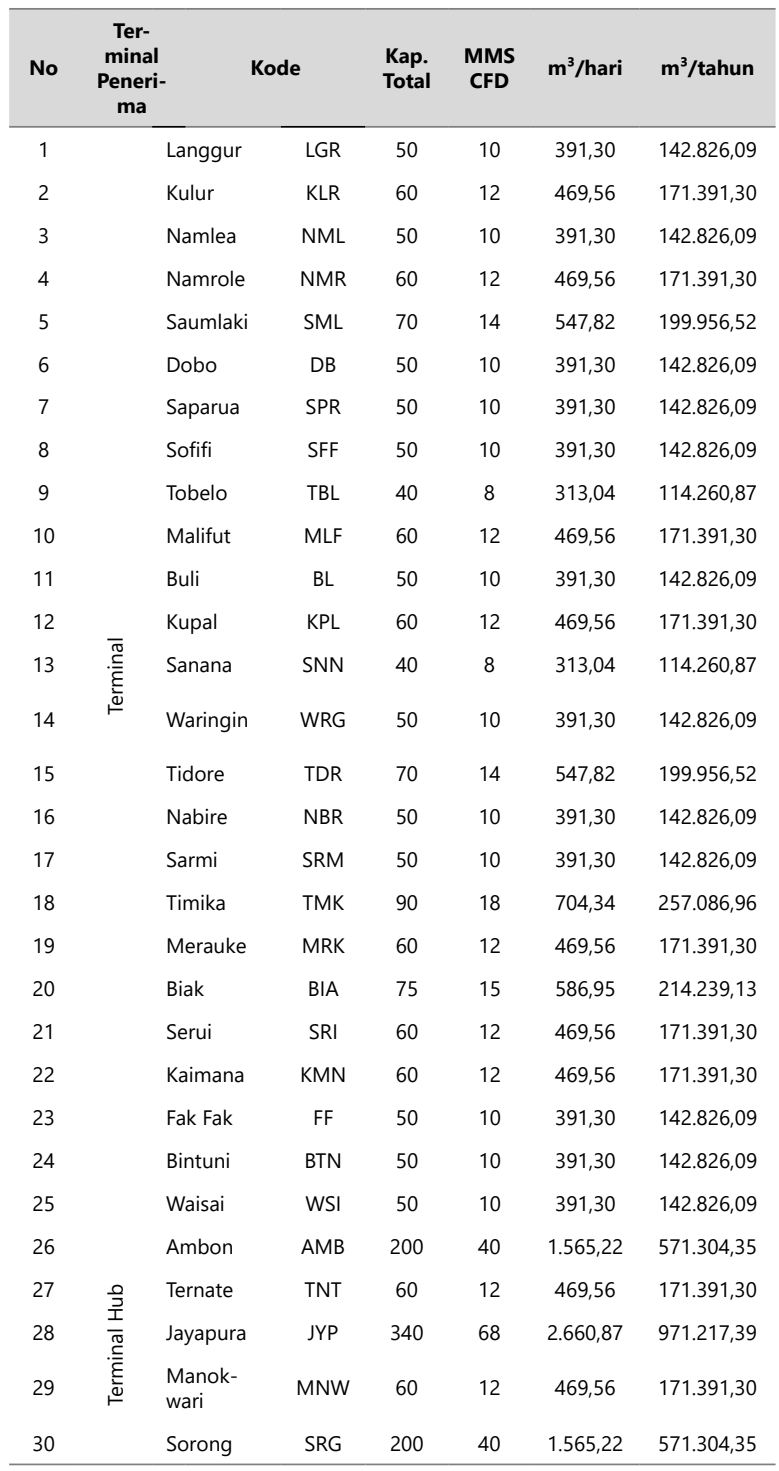

ma akhir sesuai dengan yang tercantum dalam Rencana Penyediaan Tenaga Listrik (RUPTL) 20172016. Data lokasi terminal penerima beserta jumlah permintaan LNG per tahunnya dapat dilihat pada Tabel 1.

Dalam penelitian ini, analisis mengenai alat angkut dibatasi pada perhitungan operasional saja, sehingga tidak dilakukan perhitungan teknis seperti perhitungan hambatan, stabilitas dll. Kapal yang digunakan untuk mengangkut LNG adalah kapal yang sudah tersedia. Kapal tersebut memiliki spesifikasi yang berbeda namun masih termasuk dalam kapal mini LNG.

Pada penelitian ini digunakan 5 kapal yang memiliki spesifikasi berbeda, spesifikasi 5 kapal tersebut dapat dilihat dalam Tabel 2.

Terdapat 2 (dua) opsi pola operasi kapal yang akan dianalisis dalam tugas akhir ini. Dua opsi pola operasi tersebut yaitu secara direct (langsung) dan Hub 
Tabel 2. Spesifikasi Kapal

\begin{tabular}{|c|c|c|c|c|c|c|}
\hline \multirow[b]{2}{*}{ Komponen } & \multirow{2}{*}{$\begin{array}{l}\text { Sa- } \\
\text { tuan }\end{array}$} & \multicolumn{5}{|c|}{ Alternatif Ukuran Kapal } \\
\hline & & Kapal 1 & Kapal 2 & Kapal 3 & $\begin{array}{c}\text { Kapal } \\
4\end{array}$ & $\begin{array}{c}\text { Kapal } \\
5\end{array}$ \\
\hline Nama Kapal & & Belgravia & $\begin{array}{c}\text { Coral } \\
\text { Methane }\end{array}$ & $\begin{array}{l}\text { Shortsea } \\
\text { LNG Carrier }\end{array}$ & $\begin{array}{l}\text { Shinju } \\
\text { Maru }\end{array}$ & $\begin{array}{c}\text { Pioneer } \\
\text { Knut- } \\
\text { sen }\end{array}$ \\
\hline Kapasitas Muat & $\mathrm{m}^{3}$ & 9.500 & 7.500 & 4.000 & 2.538 & 1.100 \\
\hline \multicolumn{7}{|l|}{ Ukuran Utama } \\
\hline GT & ton & 9.600 & 7.833 & 4.325 & 2.936 & 1.687 \\
\hline $\begin{array}{l}\text { Panjang } \\
\text { (LOA) }\end{array}$ & $\mathrm{m}$ & 119,80 & 117,80 & 99,00 & 86,25 & 69,00 \\
\hline Lebar (B) & $\mathrm{m}$ & 19,80 & 18,60 & 28,00 & 15,10 & 25,70 \\
\hline $\begin{array}{l}\text { Ting gi } \\
(\mathrm{H})\end{array}$ & $\mathrm{m}$ & 11,50 & 10,60 & 16,00 & 7,00 & 16,60 \\
\hline Sarat $(\mathrm{T})$ & $\mathrm{m}$ & 7,60 & 5,90 & 4,30 & 4,10 & 3,50 \\
\hline \multicolumn{7}{|l|}{ Permesinan } \\
\hline $\begin{array}{l}\text { M e s i n } \\
\text { Utama }\end{array}$ & Kw & 4.900 & 5.000 & 1.400 & 1.912 & 640 \\
\hline SFOC & $\begin{array}{l}\mathrm{kg} / \\
\mathrm{KwH}\end{array}$ & 0,185 & 0,185 & 0,185 & 0,185 & 0,185 \\
\hline $\begin{array}{l}\text { M e s i n } \\
\text { Bantu }\end{array}$ & Kw & 480 & 2.500 & 480 & 880 & 769 \\
\hline SLOC & $\begin{array}{l}\mathrm{kg} / \\
\mathrm{KwH}\end{array}$ & 0,00136 & 0,00136 & 0,00136 & 0,00136 & 0,00136 \\
\hline \multicolumn{7}{|l|}{ Kecepatan (Vs) } \\
\hline Muat & knot & 10,20 & 9,46 & 9,35 & 11,05 & 11,90 \\
\hline Kosong & knot & 12,00 & 11,13 & 11,00 & 13,00 & 14,00 \\
\hline \multicolumn{7}{|l|}{ Cargo Pump } \\
\hline Produktivitas & $\begin{array}{l}\mathrm{m}^{3} / \\
\mathrm{jam}\end{array}$ & 480 & 450 & 380 & 350 & 330 \\
\hline
\end{tabular}

and Spoke. Pengiriman secara direct (langsung), yang dimaksudkan dalam pola operasi ini adalah pengiriman yang tidak melalui terminal hub atau langsung dibawa dari lokasi kilang, tidak dikumpulkan terlebih dahulu dalam 1 (satu) titik supply.

Skema pola operasi pada penelitian ini yaitu terdapat 30 lokasi tujuan. 30 tujuan tersebut terdiri dari 25 terminal penerima akhir (Spoke) dan 5 (lima) terminal Hub. Skema pola operasi dapat dilihat pada Gambar 3.Perhitungan yang digunakan untuk menentukan jumlah rute yang memungkinkan adalah 25 terminal penerima akhir dikalikan dengan 7 (tujuh) titik asal yang tersedia sehingga menghasilkan 175 rute, kemudian ditambahkan dengan perkalian antara 5 titik terminal Hub dengan 2 (dua) titik asal yang tersedia yakni lokasi kilang. Sehingga total kemungkinan rute yang tersedia adalah 175 rute ditambahkan 10 rute menjadi 185 rute. 185 adalah jumlah keseluruhan dari rute yang memungkinkan. Maka hasil yang akan terjawab dalam model optimasi nantinya adalah menentukan lokasi asal (supply) untuk setiap titik tujuan (demand) yakni keseluruhan terminal penerima (30 tujuan).

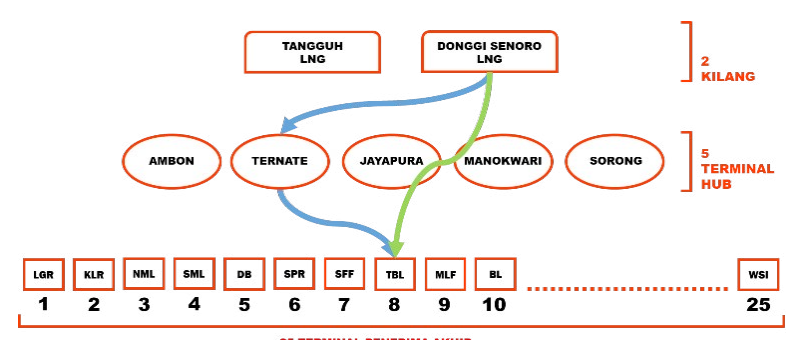

Gambar 3. Skema Pola Operasi Kapal
Tabel 3. Asumsi Operasional

\begin{tabular}{lllll}
\hline No & Komponen & Nilai & Satuan & Sumber \\
\hline 1 & Nilai Tukar 1 US\$ & 14.865 & $\mathrm{Rp}$ & Googlefinance.com \\
2 & Harga HFO & 11.650 & $\mathrm{Rp} /$ liter & pertamina.com \\
3 & Harga HSD & 14.350 & $\mathrm{Rp} /$ liter & pertamina.com \\
4 & Harga LNG & 127.469 & $\mathrm{Rp} / \mathrm{m}^{3}$ & Indexmundi.com \\
5 & Hari Kerja PLTG & 365 & Hari/tahun & \\
6 & Inflasi & 4,5 & $\%$ & Bank Indonesia \\
7 & Waktu AT+WT+IT & 5 & Jam & \\
\hline
\end{tabular}

Analisis kompatibilitas sarat kapal dengan kedalaman terminal dilakukan untuk memastikan alternatif kapal mana saja yang nantinya bisa atau tidak bisa sandar di terminal bongkarnya. Analisis dilakukan dengan membandingkan sarat dari semua opsi kapal dengan kedalaman terminal bongkar di semua rute.

Adapun asumsi yang digunakan antara lain nilai tukar rupiah terhadap US\$ adalah sebesar Rp 14.865 yang nilainya didapat dari googlefinance. com. Asumsi yang lain adalah harga HFO sebesar Rp 11.650 /liter untuk bahan bakar mesin utama kapal. Harga HSD sebesar Rp 14.350 /liter sebagai bahan bakar mesin bantu kapal dan juga sebagai salah satu bahan bakar PLTMG. Harga LNG sendiri adalah Rp 127.466 /MMBTU yang digunakan sebagai bahan bakar untuk PLTG.

Selain asumsi diatas, dalam penelitian ini juga mengasumsikan beberapa hal lain. Biaya pelabuhan yang digunakan dalam penelitian ini bersumber dari PP 11 tahun 2015 tentang tarif pelabuhan. Selain itu, dalam penelitian ini juga digunakanasumsi sewa kapal dengan perjanjian time charter berdasarkan kapasitas ruang muat (payload).

Gas alam sebagai bahan bakar pembangkit listrik ini perlu dirubah bentuk menjadi cair untuk dapat di distribusikan dengan efektif. Seperti pengkonversian 1 meter kubik LNG setara dengan 600 meter kubik gas alam. Sehingga as alam akan dicairkan menjadi LNG agar saat mengangkut dapat memuat lebih banyak. Terdapat beberapa satuan gas alam, MMSCFD biasanya digunakan sebagai satuan aliran gas. Sedangkan MMBTU digunakan untuk satuan pembelian atau penyimpanan gas alam.

\section{Perhitungan Biaya Transportasi Laut}

Sebelum mulai menghitung masing-masing komponen tersebut, diperlukan perhitungan biaya

Tabel 4. Konversi LNG

\begin{tabular}{lllll}
\hline \multicolumn{4}{c}{ GAS UNIT CONVERSION } \\
\hline 1 & MTPY & $=$ & 140 & mmscfd \\
100 & mmscfd gas & $=$ & 730.000 & TPY LNG \\
100 & mmscfd gas & $=$ & 2.100 & TPD LNG \\
100 & mmscfd gas & $=$ & 500 & MW \\
& Specific Gravity LNG & $=$ & 0,46 & \\
1 & m3 LNG & $=$ & 21,20 & mmbtu \\
\hline
\end{tabular}


waktu. Perhitungan waktu terbagi menjadi waktu kapal berlayar dan waktu kapal berlabuh. Dari total waktu maka akan didapatkan gambaran berapa lama waktu yang dibutuhkan kapal untuk menyeleseikan 1 roundtrip. Total waktu juga dapat digunakan untuk mencari berapa frekuensi maksimal kapal dalam 1 tahun. Frekuensi maksimal kapal dalam 1 tahun merupakan fungsi dari hari kerja kapal dan total waktu untuk 1 roundtrip. Komponen dari biaya transportasi laut yang digunakan pada penelitian ini adalah biaya kapital sebagai fixed cost, serta biaya perjalanan dan biaya kepelabuhan sebagai variable cost.

\section{Biaya Regasifikasi}

Biaya regasifikasi adalah biaya yang dikeluarkan untuk mengkonversi gas cair atau LNG ke bentuk gas. Proses regasifikasi ini membutuhkan fasilitas khusus yaitu fasilitas regasifikasi. Fasilitas regasifikasi bisa di letakan di darat, maupun di laut (offshore) yang biaya disebut dengan Floating Regasification Unit (FRU). Fasilitas regasifikasi juga bisa digabung dengan fasilitas penyimpanna gas atau biasa disebut dengan Floating Storage and Regasification Unit (FSRU). Tarif untuk meregasifikasi LNG dalah Rp 9.940 / MMBTU.

\section{Biaya Penyimpanan}

Biaya penyimpanan adalah biaya yang timbul akibat pemakaian fasilitas penyimpanan muatan. Tarif penyimpanan untuk LNG adalah Rp 11.360 /MMBTU. Biaya penyimpanan didapat dari perkalian antara tarif dan kebutuhan bahan bakar per tahun di masing-masing pembangkit.

\section{Investasi Terminal Penerima}

Pembangunan terminal LNG merupakan alternatif yang dipilih untuk menambah pasokan gas yang telah ditargetkan. Ada dua alternatif model pilihan untuk pembangunan terminal LNG ini yaitu Offshore (LepasPantai) dan Onshore (di daratan). Setelah dilakukan analisis pemilihan jenis terminal, hasil dari nilai investasi yang didapat menunjukkan bahwa penggunaan terminal LNG jenis FSRU lebih murah jika dibandingkan dengan pemakaian terminal LNG darat. Maka dalam penelitian ini, jenis terminal LNG yang akan digunakan adalah FSRU.

Mengacu pada jurnal berjudul "Virtual Pipeline to Support Natural Gas Infrastructures Development in Eastern Indonesia Region", beberapa proyek atau bagian dari proyek harganya dapat dikirakira dengan menggunakan rule of thumb. Rule

Tabel 5. Rule of Thumbs Pertamina

\begin{tabular}{|c|c|c|c|c|}
\hline \multicolumn{2}{|c|}{ Category } & \multirow{2}{*}{$\begin{array}{c}\text { Pertamina } \\
\text { Rule of } \\
\text { Thumbs }\end{array}$} & \multirow{2}{*}{$\begin{array}{l}\text { Unit Cost } \\
\text { US \$ million/ } \\
\text { MMSCFD }\end{array}$} & \multirow{2}{*}{$\begin{array}{c}\text { Remarks } \\
>60 \text { MMSCFD }\end{array}$} \\
\hline $\begin{array}{l}\text { Liquefac- } \\
\text { tion }\end{array}$ & $\begin{array}{l}\text { Large LNG } \\
\text { Plant }\end{array}$ & & & \\
\hline \multirow{3}{*}{$\begin{array}{l}\text { Regasifi- } \\
\text { cation }\end{array}$} & $\begin{array}{l}\text { Mini LNG } \\
\text { Plant }\end{array}$ & 5 & $\begin{array}{l}\text { US \$ million/ } \\
\text { MMSCFD }\end{array}$ & $<20$ MMSCFD \\
\hline & FSRU & 0,6 & $\begin{array}{l}\text { US \$ million/ } \\
\text { MMSCFD }\end{array}$ & \\
\hline & Land-based & 2,1 & $\begin{array}{l}\text { US \$ million/ } \\
\text { MMSCFD }\end{array}$ & \\
\hline
\end{tabular}

of thumb ini digunakan sebagai cara cepat untuk estimasi hasil dari interpolasi dan ekstrapolasi proyek terdahulu. Tabel di bawah menunjukkan asumsi investasi proyek FSRU dari Pertamina sebagai acuan dalam menghitung berapa besar biaya investasi yang diperlukan untuk membangun sebuah FSRU.

\section{Total Biaya dan Biaya Satuan}

Total biaya keseluruhan didapatkan dari penjumlahan biaya transportasi laut yang terdiri dari biaya sewa kapal, biaya perjalanan, dan biaya kepelabuhanan dengan biaya penanganan LNG, biaya regasifikasi biaya penyimpanan di terminal dan investasi terminal penerima. Dari total biaya, untuk mencari biaya satuan maka total biaya keseluruhan dibagi dengan jumlah kargo terkirim.

\section{Model Optimasi}

Model optimasi merupakan metode yang digunakan pada penelitian ini dengan menggunakan aplikasi solver pada Microsoft Excel. Dalam penelitian ini, dikarenakan jumlah kemungkinan rute dan alternatif kapal ada banyak maka penggunaan solver biasa tidak bisa diaplikasikan. Sebagai solusi perlu ditambahkan aplikasi tambahan yakni Open Solver yang bisa menjalankan model hingga 2000 variabel. Model optimasi disusun untuk menentukan pola operasi, pemilihan armada kapal, dan pemilihan jenis terminal penerima dengan total biaya paling minimum

\section{Hasil Model Optimasi}

Setelah melakukan perhitungan seluruh komponen biaya total, dilakukan proses optimasi. Dari hasil optimasi tersebut akan menghasilkan ruterute terpilih beserta kapal yang paling optimum dengan total biaya paling minimum.

Tabel 6 menjelaskan bahwa dari total terminal Hub yang sebelumnya ada 5 (lima), hanya 3 (tiga) lokasi saja yang dapat mensuplai kebutuhan LNG terminal penerima lain secara optimal. Hasil optimasi menunjukkan bahwa Hub Jayapura dan Hub Sorong tidak akan optimal jika dijadikan sebagai terminal Hub karena tidak memiliki satu pun tujuan

Tabel 6. Rute Asal-Tujuan Hasil Optimasi

\begin{tabular}{|c|c|c|c|c|c|c|}
\hline Hub & Hub & Hub & Hub & Hub & Langsung & Langsung \\
\hline Ambon & Ternate & $\begin{array}{c}\text { Jaya- } \\
\text { pura }\end{array}$ & $\begin{array}{c}\text { Manok- } \\
\text { wari }\end{array}$ & $\begin{array}{c}\text { So- } \\
\text { rong }\end{array}$ & $\begin{array}{l}\text { (Tangguh } \\
\text { LNG) }\end{array}$ & (DS LNG) \\
\hline Kulur & Sofifi & - & Nabire & - & Langgur & $\begin{array}{l}\text { Hub } \\
\text { Ambon }\end{array}$ \\
\hline Namlea & Tobelo & & Sarmi & & Dobo & $\begin{array}{l}\text { Hub } \\
\text { Ternate }\end{array}$ \\
\hline Namrole & Malifut & & Biak & & Kaimana & \\
\hline Saumlaki & Buli & & Serui & & Fakfak & \\
\hline Saparua & Kupal & & Waisi & & Bintuni & \\
\hline \multirow[t]{5}{*}{ Sanana } & $\begin{array}{l}\text { War- } \\
\text { ingin }\end{array}$ & & & & Timika & \\
\hline & Tidore & & & & Merauke & \\
\hline & & & & & Jayapura & \\
\hline & & & & & Sorong & \\
\hline & & & & & $\begin{array}{l}\text { Hub Ma- } \\
\text { nokwari }\end{array}$ & \\
\hline
\end{tabular}


terminal penerima akhir untuk disuplai. Maka dari itu, Hub Jayapura dan Hub Sorong akan dijadikan sebagai terminal penerima biasa yang berdasarkan hasil optimasi akan disuplai kebutuhan LNG per tahunnya langsung dari lokasi kilang di Tangguh. Sedangkan untuk 3 (tiga) lokasi terminal Hub terpilih masing-masing akan disuplai dari kilang Dongi-Senoro untuk Hub Ambon-Ternate dan kilang Tangguh untuk Hub Manokwari. Berikut penjelasan mengenai masing-masing pola pengiriman yang terpilih. Hasil yang akan ditampilkan berdasarkan wilayah masing-masing provinsi dan berdasarkan pola pengimannya (langsung dan Hub Spoke).

\section{Pengiriman Hub and Spoke}

Pola operasi Hub and Spoke merupakan pola operasi dimana kapal utama yang berangkat dari kilang melakukan transit di terminal Hub, dimana terminal Hub tersebut menjadi terminal pengumpul pasokan LNG dari kilang untuk kemudian dikirimkan ke semua terminal tujuan akhir dengan menggunakan kapal feeder.

\section{1) Hub Ambon}

Terdapat 6 (enam) titik dari 25 titik tujuan terminal akhir yang disuplai dari terminal Hub Ambon berdasarkan hasil optimasi yang terpilih. Enam titik tersebut yakni Sanana, Namrole, Namlea, Kulur, Saparua dan Saumlaki. Berikut rincian hasil optimasi pengiriman melalui Hub Ambon dari 6 (enam) titik terminal akhir yang terpilih.

Dari keseluruhan biaya untuk masing-masing rute, biaya total terbesar yang timbul adalah sebesar Rp 23 milliar per tahun dengan biaya satuan sebesar 0,4 Jt-Rp/m³. Angka tersebut didapat dari biaya total dan biaya satuan rute dengan tujuan terminal penerima akhir Saumlaki. Sedangkan biaya total terkecil yang timbul adalah dari rute pengiriman Ambon-Saparua sebesar Rp 17 miliiar per tahun untuk biaya total dan $1,16 \mathrm{Jt}-\mathrm{Rp} / \mathrm{m}^{3}$ untuk biaya satuan.

\section{2) Hub Ternate}

Terdapat 7 (tujuh) titik dari 25 titik tujuan terminal akhir yang disuplai dari terminal Hub Ternate berdasarkan hasil optimasi yang terpilih. Tujuh titik tersebut adalah Waringin, Tobelo, Malifut, Buli,

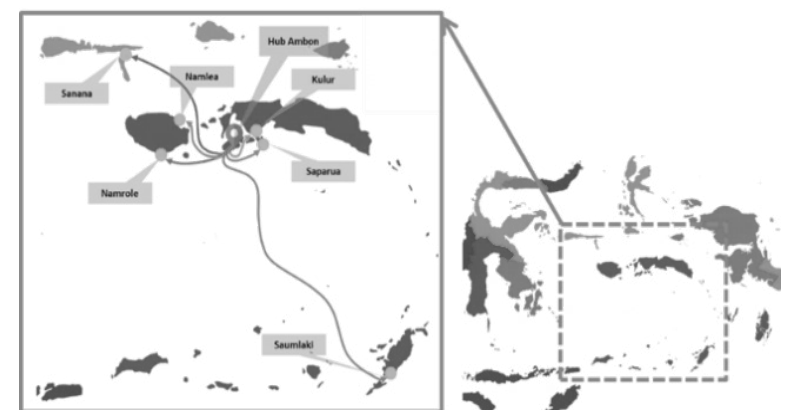

Gambar 4. Rute Terpilih Hub Ambon

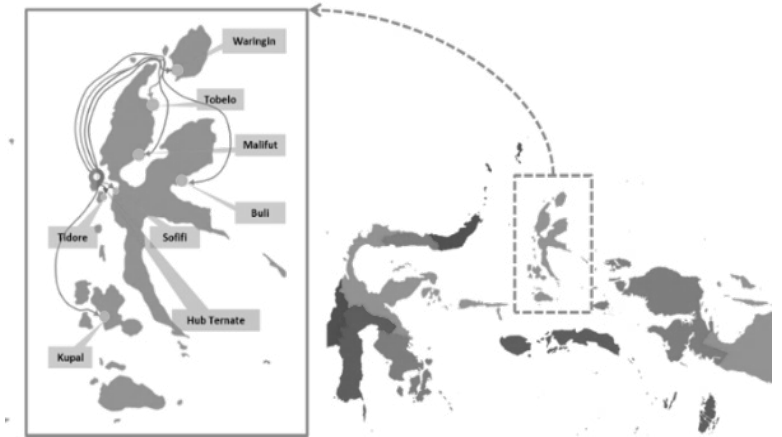

Gambar 5. Rute Terpilih Hub Ternate

Kupal, Tidore dan Sofifi. Berikut rincian hasil optimasi pengiriman melalui terminal Hub Ternate dari 7 (tujuh) titik terminal akhir yang terpilih.

Dari keseluruhan biaya untuk masing-masing rute, biaya total terbesar yang timbul adalah sebesar Rp 30 milliar per tahun dengan biaya satuan sebesar Rp 590.000 per $\mathrm{m}^{3}$. Angka tersebut didapat dari biaya total dan biaya satuan rute dengan tujuan terminal penerima akhir Malifut. Sedangkan biaya total terkecil yang timbul adalah dari rute pengiriman Ternate-Sofifi sebesar Rp 28 miliar per tahun untuk biaya total dan Rp 90.000 per $\mathrm{m}^{3}$ untuk biaya satuan.

\section{3) Hub Manokwari}

Terdapat 5 (lima) titik dari 25 titik tujuan terminal akhir yang disuplai dari terminal Hub Manokwari berdasarkan hasil optimasi yang terpilih. Lima titik tersebut adalah Waisai, Nabire, Serui, Biak dan Sarmi. Berikut rincian hasil optimasi pengiriman melalui terminal Hub Manokwari dari 5 (lima) titik terminal akhir yang terpilih.

Dari keseluruhan biaya untuk masing-masing rute, biaya total terbesar yang timbul adalah sebesar Rp 31 milliar per tahun dengan biaya satuan sebesar Rp 150.000 per $\mathrm{m}^{3}$ untuk rute Manokwari-Serui. Sedangkan biaya total terkecil yang timbul adalah dari rute pengiriman Manokwari-Biak sebesar Rp 22 miliiar per tahun untuk biaya total dan Rp 1.570.000 per $\mathrm{m}^{3}$ untuk biaya satuan.

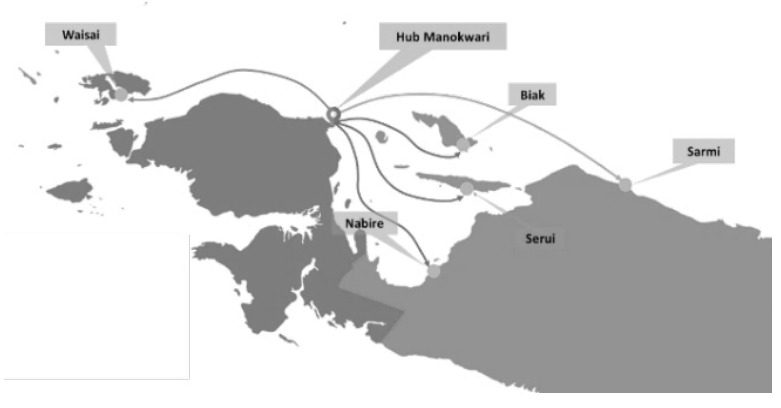

Gambar 6. Rute Terpilih Hub Manokwari 


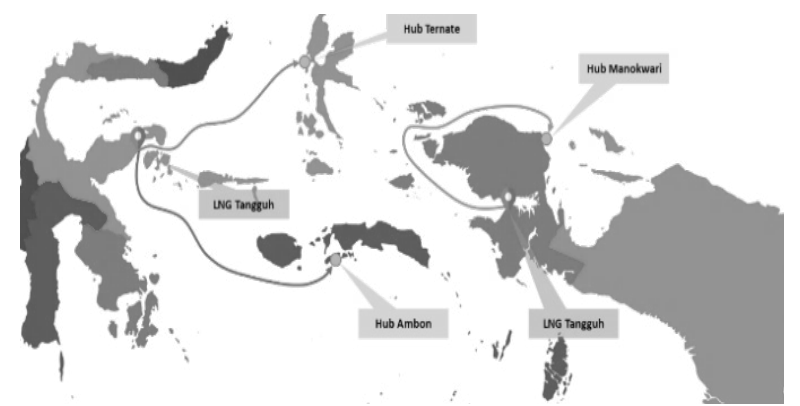

Gambar 7. Rute Pengiriman Langsung dari Kilang Asal ke 3 Terminal Hub

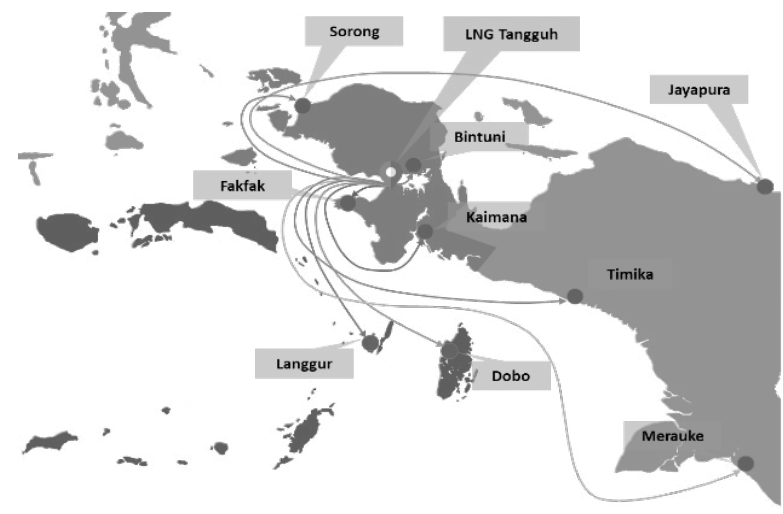

Gambar 8. Rute Pengiriman Langsung Terminal Penerima Akhir

\section{Pengiriman Langsung}

Pengiriman secara langsung adalah pengiriman yang tidak melalui terminal hub atau langsung dibawa dari lokasi kilang, tidak dikumpulkan terlebih dahulu dalam 1 (satu) titik supply.

Terdapat 9 (sembilan) titik dari 25 titik tujuan terminal akhir yang pola pengirimannya menggunakan pola pengiriman secara langsung (direct) berdasarkan hasil optimasi yang terpilih. Seluruh rute tersebut berasal dari 1 (satu) titik supply yang sama yakni kilang LNG Tangguh. Dalam pola pengiriman secara langsung yang terpilih untuk tujuan terminal penerima akhir, tidak ada rute yang tujuannya disuplai dari kilang Donggi Senoro. Hal ini dikarenakan ketujuh lokasi terminal tersebut lebih dekat dengan kilang LNG Tangguh daripada kilang LNG Donggi Senoro.

Sedangkan untuk ketiga terminal Hub, lokasi kilang yang mensuplai masing-masing adalah Kilang Donggi Senoro untuk Hub Ambon-Ternate dan Kilang Tangguh untuk Hub Manokwari. Berikut rincian hasil optimasi pengiriman secara langsung untuk 9 (sembilan) titik terminal penerima akhir dan 3 (tiga) terminal Hub yang terpilih.

Dari keseluruhan biaya untuk masing-masing rute, biaya total terbesar yang timbul adalah sebesar Rp 622 milliar per tahun dengan biaya satuan sebesar Rp 290.000 per $\mathrm{m}^{3}$. Angka tersebut didapat dari
Tabel 9. Perhitungan Komponen Biaya dan Biaya Total

\begin{tabular}{cccccc}
\hline No. & Tujuan & $\begin{array}{c}\text { Biaya Total } \\
\text { BBM } \\
\text { (Jt-Rp/ } \\
\text { tahun) }\end{array}$ & $\begin{array}{c}\text { Biaya Pela- } \\
\text { buhan } \\
\text { (Jt-Rp/ } \\
\text { tahun) }\end{array}$ & $\begin{array}{c}\text { Biaya } \\
\begin{array}{c}\text { Penanganan } \\
\text { Muatan } \\
\text { (Jt-Rp/tahun) }\end{array}\end{array}$ & $\begin{array}{c}\text { Biaya Sewa } \\
\text { Kapal } \\
\text { (Jt-Rp/ } \\
\text { tahun) }\end{array}$ \\
\hline 1 & LGR & $12.627,99$ & 378,52 & 13,47 & $7.679,83$ \\
2 & DB & $8.593,24$ & 227,11 & 8,08 & $5.281,95$ \\
3 & KMN & $4.394,66$ & 151,41 & 5,39 & $3.305,54$ \\
4 & FF & $2.101,76$ & 154,71 & 5,51 & $3.410,53$ \\
5 & MRK & $41.922,44$ & 454,23 & 16,17 & $22.050,53$ \\
6 & BTN & 561,39 & 165,72 & 2,69 & $1.035,30$ \\
7 & TMK & $50.282,29$ & $1.491,48$ & 24,25 & $18.547,81$ \\
8 & JYP & $199.234,18$ & 875,69 & 91,62 & $105.737,58$ \\
9 & SRG & $30.699,57$ & 515,11 & 53,90 & $35.245,86$ \\
10 & MNW & $224.735,52$ & $1.957,43$ & 204,81 & $140.983,44$ \\
11 & AMB & $86.576,17$ & 849,93 & 88,93 & $70.491,72$ \\
12 & TNT & $51.489,31$ & 605,26 & 63,33 & $35.245,86$ \\
\hline & & & & & \\
\hline
\end{tabular}

Tabel 10. Perhitungan Komponen Biaya Beserta Biaya Total (lanjutan)

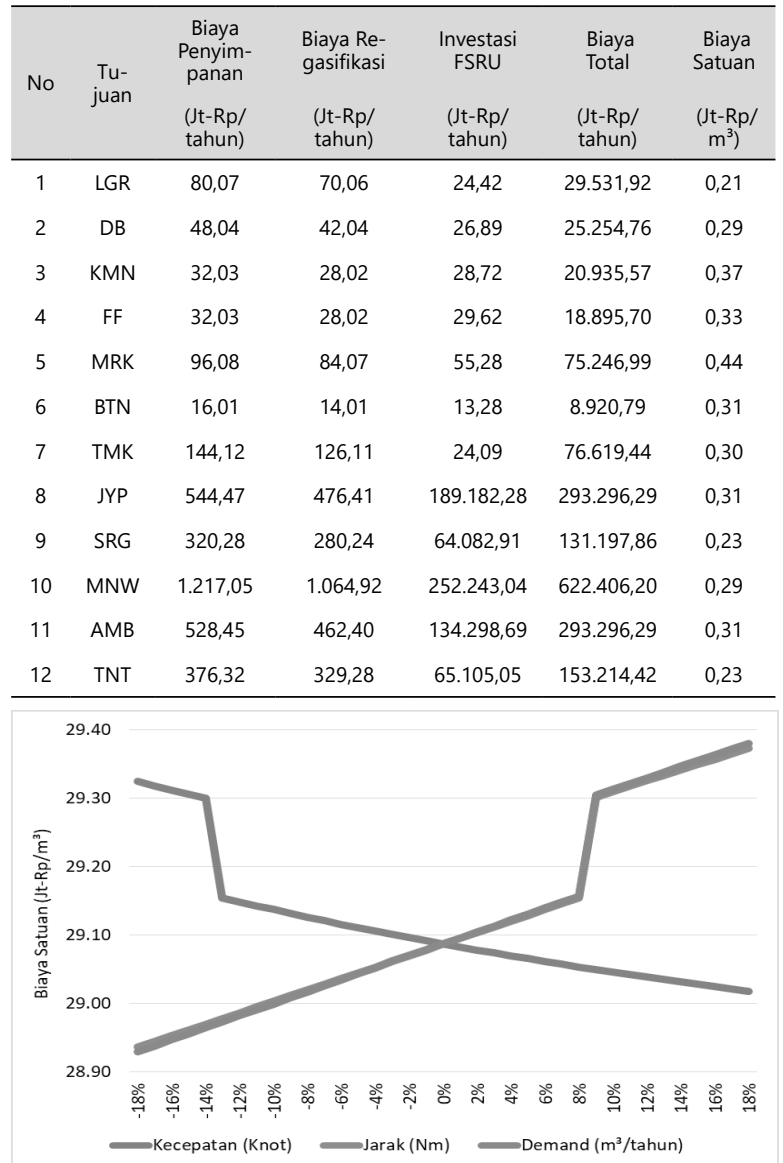

Gambar 9. Grafik Analisis Sensitivitas

biaya total dan biaya satuan rute dengan tujuan terminal penerima akhir di Manokwari sebagai terminal Hub. Sedangkan biaya terkecil yang timbul adalah dari rute pengiriman Tangguh - Bintuni sebesar Rp 8 miliiar per tahun untuk biaya total dan Rp 310.000 per $\mathrm{m}^{3}$ untuk biaya satuan. 


\section{Analisis Sensitivitas}

Pada gambar 9 diatas menunjukkan tingkat kenaikan dan penurunan tiga faktor komponen yang mempengaruhi besarnya biaya satuan. Penurunan kecepatan kapal sebesar 18\% akan membuat biaya satuan naik sekitar $0,81 \%$. Sebaliknya jika kecepatan dinaikan hingga $18 \%$ maka akan menurunkan biaya satuan sekitar 0,24\%. Berbeda dengan komponen jarak, semakin jauh jarak tempuh kapal maka semakin mahal pula biaya satuannya. Sebaliknya jika semakin dekat jarak maka biaya satuan akan semakin murah. Sedangkan untuk komponen demand, kenaikan dan penurunan sebesar 18\% hasilnya sama dengan komponen jarak untuk tingkat kenaikan dan penurunan biaya satuan per $\mathrm{m}^{3}$ nya.

\section{KESIMPULAN DAN SARAN}

Berdasarkan analisis data dan pembahasan yang telah dilakukan pada studi ini mengenai perencanaan transportasi terpadu angkutan LNG untuk pembangkit di Kepulauan Maluku dan Papua, maka dapat ditarik kesimpulan dari hasil yang telah didapat sebagai berikut:

1. Melalui model optimasi linear programming dengan fungsi objektif minimum biaya satuan maka didapat perencanaan rute optimum pasokan LNG untuk seluruh pembangkit listrik di wilayah Maluku dan Papua menggunakan 2 pola pengiriman yakni secara langsung dari kilang (Direct) dan melalui terminal Hub (Hub Spoke).

2. Melalui model optimasi linear programming dengan fungsi objektif minimum biaya satuan maka terpilih kapal untuk setiap rute dengan rincian:

- Tangguh menuju Langgur, Dobo dan Kaimana dilayani kapal dengan kapasitas $2.538 \mathrm{~m}^{3}$ sejumlah 1 unit untuk seluruh rute.

- Tangguh menuju Fakfak dan Merauke dilayani kapal kapasitas $2.538 \mathrm{~m}^{3}$ sejumlah 1 unit untuk kedua rute.

- Tangguh menuju Bintuni dan Timika dilayani kapal kapasitas $1.100 \mathrm{~m}^{3}$ sejumlah 1 unit untuk kedua rute.

- Tangguh menuju Jayapura, Sorong dan Hub Manokwari dilayani kapal kapasitas $9.500 \mathrm{~m}^{3}$ sejumlah 1 unit untuk masing-masing rute.

- Donggi Senoro menuju Hub Ambon dan Hub Ternate dilayani kapal kapasitas $9.500 \mathrm{~m}^{3}$ sejumlah 1 unit untuk masing-masing rute.

- Hub Ambon menuju Kulur, Namlea, Namrole, Saumlaki, Saparua dan Sanana disuplai kapal kapasitas $2.538 \mathrm{~m}^{3}$ sejumlah 1 unit untuk keseluruhan rute.

- Hub Ternate menuju Sofifi, Tobelo, Malifut, Buli, Kupal, Waringin dan Tidore disuplai kapal kapasitas $2.538 \mathrm{~m}^{3}$ sejumlah 1 unit un- tuk keseluruhan rute

- Hub Manokwari menuju Nabire, Sarmi, Biak, Serui dan Waisai dilayani kapal kapasitas $4.000 \mathrm{~m}^{3}$ sejumlah 1 unit untuk keseluruhan rute.

Dengan menjumlahkan biaya transportasi laut yang terdiri dari biaya sewa kapal, biaya perjalanan, dan biaya kepelabuhanan dengan biaya penanganan LNG, biaya regasifikasi, biaya penyimpanan dan investasi terminal maka didapat total biaya keseluruhan rute sebesar 1,4 Triliun-Rp per tahun dengan kargo terangkut sebanyak 2,12 juta ton per tahun. Dari total biaya yang didapat kemudian dibagi total permintaan untuk semua rute maka didapat biaya satuan sebesar 29,09 Jt-Rp per $\mathrm{m}^{3}$.

\section{DAFTAR PUSTAKA}

Arif Rakhmawan, Widodo W. Purwanto, "Optimisasi Rantai Suplai Mini LNG untuk Pembangkit Listrik di Wilayah Indonesia Timur", Teknik Kimia, Universitas Indonesia, 2014.

Aritonang, Supriyadi, \& Silalahi, "Energy Diversification Indonesian Railways," Pertahanan, Vol. 2, No. 3, pp. 193-212, 2016. [Online]. Issn: 2087-9415. [Online]. DOI: 10.3390.

Guzel, "LNG Supply chain analysis and optimisation if Turkey's natural gas need with LNG import," (2011). World Maritime University Dissertations. 44.

H. Hashimoto, S. Yoneda, Y. Tahara and E. Kobayashi, "CFD-Based Study on the Prediction of Wave-Induced Surge Force," Ocean Engineering, vol. 120, pp. 389-397, 2016.

Muhammad Rum Pandu Nuswantara, Wiryawan Priharnanto, Gede Wibawa," Regasification of LNG (Liquified Natural Gas), vol. 3, No. 2, pp. 149-152, 2014. [Online]. ISSN: 23373539.

M. Iqbal and G. Rindo, "Pengaruh Anti-Slamming Bulbous Bow Terhadap Gerakan Slamming Pada Kapal Perintis 200 DWT," KAPAL, vol. 13 , no. 1 , pp. 45-54, 2016. [Online]. DOI: 10.12777/kpl.13.1.45-54 [Diakses 9 Februari 2017].

M. Iqbal and I. K. A. P. Utama, "An Investigation into the Effect of Water Depth on the Resistance Components of Trimaran Configuration," in The 9 th International Conference on Marine Technology, Surabaya, 2014. 
30 | Yunianto, I.T. dkk. Model Jaringan Transportasi Laut Angkutan Gas Alam Cair..

Nurhadi Budi Santoso, "Pemanfaatan LNG Sebagai Sumber Energi di Indonesia," Rekayasa Proses, Vol. 8, No. 1, 2014.

O. M. Faltinsen, Hydrodynamics of High-Speed Marine Vehicle, Cambridge: Cambridge University Press, 2005.

Philip Ejoor Agbonifo, "Natural Gas Distribution Infrastructure and The Quest for Enviromental Sustainability in The Niger Delta: The Prospect of Natural Gas Utilization in Nigeria," Energy Economics and Policy, Vol. 6, No. 3, pp. 442-448, 2016. ISSB: 2146-4553.
Randeep Agarwal, Thomas J. Rainey, S.M. Ashrafur Rahman, Ted Steinberg, Robert K. Perrons and Richard J. Brown., "LNG Regasification Terminals: The Role of Geography and Meteoroly on Technology Choices" Energies, 2017, doi: 10.3390/EN10122152.

W. S. Vorus, "Vibration," in Principle of Naval Architecture Series, Jersey City, The Society of Naval Architects and Marine Engineers, 2010 